\title{
3 Advanced Exergy Analysis of an Oil Shale Retorting Process
}

4

5

6

7

8

*Corresponding author:

21 Professor Siyu Yang Ph.D.

22 School of Chemical Engineering

23 South China University of Technology

24 Guangzhou, 510640, P. R. China.

25

Phone: +86-20-87112056

26

Email: cesyyang@scut.edu.cn P.O. Box 20, FI-53851 Lappeenranta, Finland ul. Wolczanska 213, 90-924 Lodz, Poland

${ }^{\mathbf{b}}$ LUT School of Business and Management, Lappeenranta University of Technology,

${ }^{\mathbf{c}}$ Faculty of Process and Environmental Engineering, Lodz University of Technology, 


\section{Abstract}

2 Fushun-type process is the most common method of oil shale retorting used in

3 China. The process is, however, characterized by poor thermodynamic performance.

4 While conventional exergy analysis is able to quantitatively determine exergy 5 destruction in a system, identification of the sources of the exergy destruction, and 6 thus identification of areas with the greatest potential for efficiency improvement, 7 requires advanced exergy analysis. In this paper, an advanced exergy analysis is 8 applied to evaluate the performance of a Fushun-type oil shale retorting process.

9 The results indicate that, the simulation results are consistent with industrial data.

10 The process can produce $21.90 \mathrm{t} / \mathrm{h}$ of shale oil from $500 \mathrm{t} / \mathrm{h}$ oil shale. The exergy

11 efficiency of the Fushun-type oil shale retorting process studied in this work is $34.17 \%$

12 and the total exergy destruction is $442.62 \mathrm{MW}$. The analysis shows that $45.40 \%$ of the 13 exergy destruction cannot be reduced. The retort is found to be the element of the 14 Fushun-type oil shale retorting process having the greatest potential for decrease in 15 exergy destruction. Improvement strategies are proposed to minimize exergy 16 destruction in the retort.

17

18 Key words: oil shale retorting; conventional exergy analysis; advanced exergy 19 analysis; process simulation; improvement strategy 


\section{$1 \quad$ 1. Introduction}

Finite world oil supplies are one of the major drivers of increasing attention to

3 the exploitation of alternative, non-traditional energy sources [1]. One such alternative,

4 oil shale is found worldwide and is regarded as a most promising alternative to crude

5 oil [2]. The extractable amount of shale oil is estimated as $6.89 \times 10^{11} \mathrm{t}$, three times the world's crude oil reserves [3], and shale oil reserves in China total $4.76 \times 10^{10} \mathrm{t}$, double

7 the country's crude oil reserves [4]. Effective exploitation of oil shale could relieve

8 shortages of crude oil, reduce dependence on imported oil, and enhance the structure

9 of energy resources in China and many other countries.

Several oil shale retorting processes are in industrial use, e.g. the Brazilian

11 Petrosix [5], Estonian Kiviter and Galoter [6] and Chinese Fushun-type [7] processes.

12 Fushun-type oil shale retorting technology has many advantages, such as simplicity, 13 considerable adaptability and reliable operation. It has been widely used in China. In 14 2014, there were about 605 sets of retorts running in China [8], of which 546 were 15 Fushun-type [1]. A block diagram of the Fushun-type oil shale retorting (FsOSR) 16 process is shown in Fig.1. In this process, oil shale is converted into shale oil, retorting gas and char. Despite its advantages, the Fushun-type oil shale retorting

18 process is, however, characterized by the significant drawbacks of low oil yield and 19 poor energy efficiency $[9,10]$. These drawbacks motivate the current research on the FsOSR process. Better understanding of the physical and chemical processes involved

21 and improved mathematical modeling and simulation can contribute to endeavors to 22 reduce energy loss of the FsOSR process.

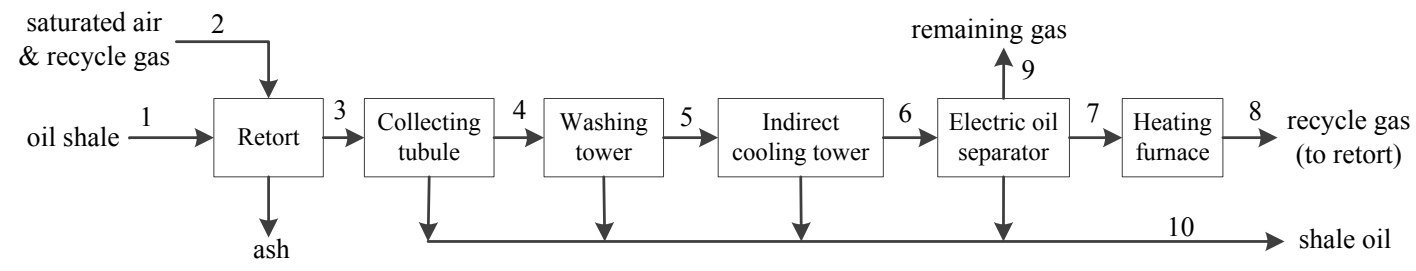

Fig. 1. Block diagram of the FsOSR process 
In recent years, intensive studies have been conducted on modelling and

2 simulation of oil shale retorting process. For example, Bai et al. [11] simulated a

3 Huadian-type oil shale process. Wang et al. [12] studied an oil shale retorting process

4 with a gas-heat carrier. Wang et al. [13] investigated utilization options of Chinese oil

5 shale resources. Bai et al. [14] and Qian et al [9] researched Fushun-type oil shale

6 retorting process. These studies, focusing on building of the retort model, validated

7 the feasibility of Aspen plus software for simulation of the oil shale retorting process.

8 However, little work has been done to model and simulate the complete FsOSR

9 process, and there is a lack of research analyzing the thermodynamic performance of

10 the whole FsOSR process. Li et al. [15] used conventional exergy analysis to analyze

11 and compare three typical retorting technologies: the FsOSR, the gas full-circulation

12 retorting process, and the Dagong retorting method. The obtained results showed that

13 the FsOSR technology had the biggest exergy destruction ratio, 65.7\%. It is 1.70

14 times higher than that of the Dagong retorting process and 1.27 times higher than that

15 of the gas full-circulation retorting process. This result indicates the urgency of

16 research on improvement of the thermodynamic performance of the FsOSR process.

17 The inefficiency of the FsOSR process can be quantitatively determined by

18 conventional exergy analysis. However, conventional exergy analysis cannot identify

19 the share of inefficiencies that can be avoided [16]. Moreover, conventional exergy

20 analysis cannot assess the interactions between the components of the system or the

21 improvement potential of each component $[17,18]$.

22 In this paper, advanced exergy analysis is used to address this issue. The 23 approach divides exergy destruction into two main groups: endogenous/exogenous 24 exergy destruction and avoidable/unavoidable exergy destruction. Advanced exergy 25 analysis is able to determine the share of the inefficiency caused by the interactions of 26 the systems' components and what inefficiency could be avoided by technological 27 improvement [19]. The method has been applied previously to analyze natural gas 28 liquefaction [18, 20], an LNG-based cogeneration system [21], a supercritical 
1 coal-fired power plant [22, 23], a combined cycle power plant [19, 24], an absorption

2 refrigeration machine [25-27], and a food drying process [28]. To date, however, no

3 works have been published on the application of advanced exergy analysis to the oil

4 shale retorting process.

The main objectives of this work are: (1) For the first time, to apply the advanced exergy analysis to the oil shale retorting process; (2) to investigate the interactions between system components and their improvement potential; (3) to propose a four-step method for application of the advanced exergy analysis to the FsOSR process; and (4) to suggest possible improvement strategies to increase the thermodynamic performance of the FsOSR process.

\section{Process description}

A flowsheet of the studied Fushun-type oil shale retorting process is shown in Fig. 2. The process consists of two stages: retorting and gasification. The oil shale, with a diameter of $10-75 \mathrm{~mm}$, enters the retorting stage. In this stage, oil shale is converted into shale oil, retorting gas, and semi-coke at $0.1 \mathrm{MPa}$ and $525^{\circ} \mathrm{C}$ [29]. The semi-coke is fed to the gasification stage, where it reacts with carbon dioxide and steam at $950^{\circ} \mathrm{C}$. The fixed carbon in the semi-coke is converted into $\mathrm{CO}, \mathrm{CO}_{2}, \mathrm{H}_{2}$, and $\mathrm{CH}_{4}$. As the semi-coke enters the last part of the gasification stage, it is burnt with air. The oil-gas mixture from the retort is fed to a collecting tube to separate the shale oil. In the collecting tube, the oil-gas mixture is cooled by water to a temperature of about $85^{\circ} \mathrm{C}$. The mixture is then cooled in the washing and indirect cooling towers to recover more shale oil. The outlet stream from the indirect cooling tower reaches about $40^{\circ} \mathrm{C}$. The stream is next fed into an electric oil separator in order to improve the separation of the shale oil. The retorting gas exiting from the electric oil separator is divided into three streams: (1) recycle gas, to be re-fed into the retort; (2) burning gas, to heat the recycle gas; and (3) byproduct gas, to be eventually used for power generation or the production of chemical products. 


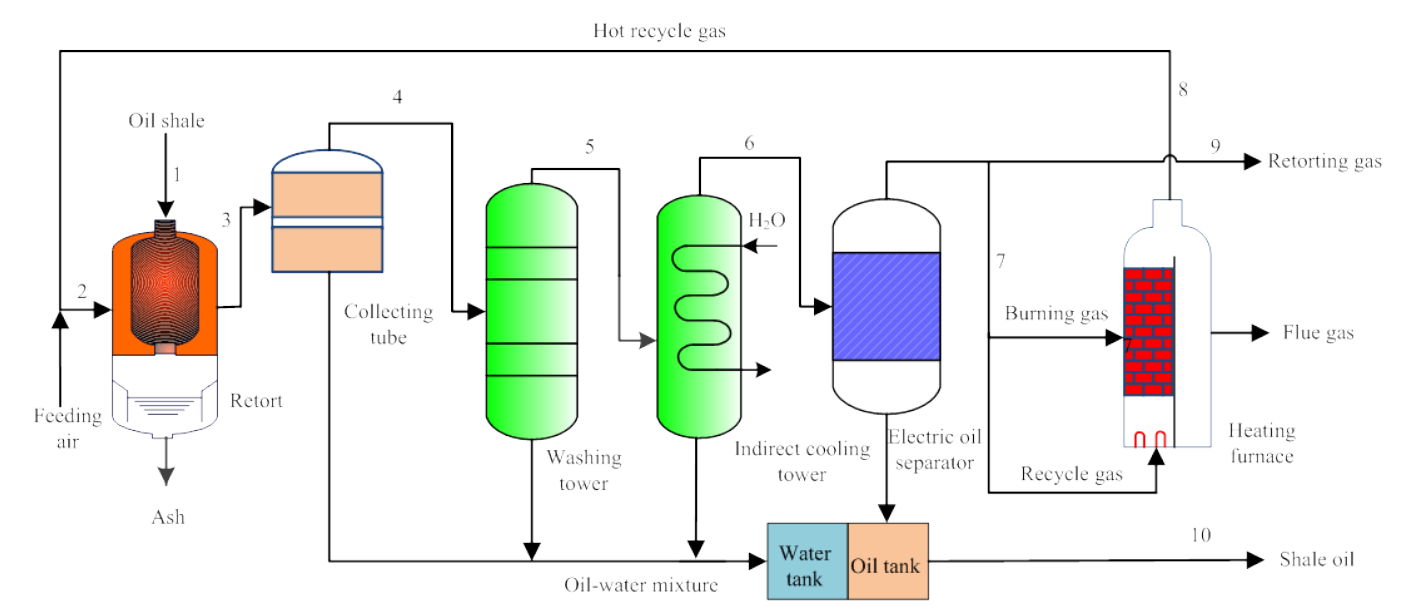

Fig. 2. Flowsheet of the FsOSR process

\section{3. Methodology of the process analysis}

The advanced exergy analysis method applied to the FsOSR process is summarized in the flow diagram shown in Fig. 3. It comprises four steps:

1. Process modeling and simulation. Mathematical models of the FsOSR process are built, simulation is conducted, and the results are validated.

2. Conventional exergy analysis. The key thermodynamic parameters (such as enthalpy, entropy, temperature, and stream compositions) obtained in Step 1 are used to perform conventional exergy analysis. The exergy destruction is determined by calculating the exergy balance for each component. The performance of each component is determined by calculation of the exergy efficiency and exergy destruction ratio.

3. Advanced exergy analysis. The operating conditions of the system are adjusted on the basis of technological and economical limitations. The new mass and the exergy balances of the system are formulated with respect to theoretically optimal operating conditions and practically optimal operating conditions.

The practical conditions are used for conventional exergy analysis. The endogenous/exogenous exergy destruction is calculated with the theoretically optimal conditions. Unavoidable/avoidable exergy destruction is calculated using the defined 
1 maximum permissible values, i.e. theoretically optimal and practically feasible

2 operating conditions. The exergetic product for whole system is assumed to be

3 constant. Using the information obtained from conventional and advanced exergy

4 analysis, the endogenous/exogenous and unavoidable/avoidable exergy destructions

5 are calculated. Four terms are defined: unavoidable-endogenous exergy destruction

$6 \quad\left(E_{\mathrm{D}, \mathrm{k}}^{\mathrm{UN}, \mathrm{EN}}\right)$, unavoidable-exogenous exergy destruction $\left(E_{D, k}^{U N, E X}\right)$, avoidable-endogenous

7 exergy destruction $\left(E_{D, k}^{A V, E N}\right)$ and avoidable-exogenous exergy destruction $\left(E_{D, k}^{A V, E X}\right)$

8 [30]. Detailed definitions and equations are given in the next section.

9 4. Improvement strategy. In this step, the first objective is to find the 10 component that has the greatest impact on the total avoidable exergy destruction of 11 the whole system. Priority is then given to this component when searching for the 12 utilization possibilities for the avoidable exergy destruction ( $E_{D, k}^{A V, E N}$ and $\left.E_{D, k}^{A V, E X}\right)$.

13 Efficient improvement priorities are then proposed for reduction of the endogenous 14 and exogenous exergy destruction.

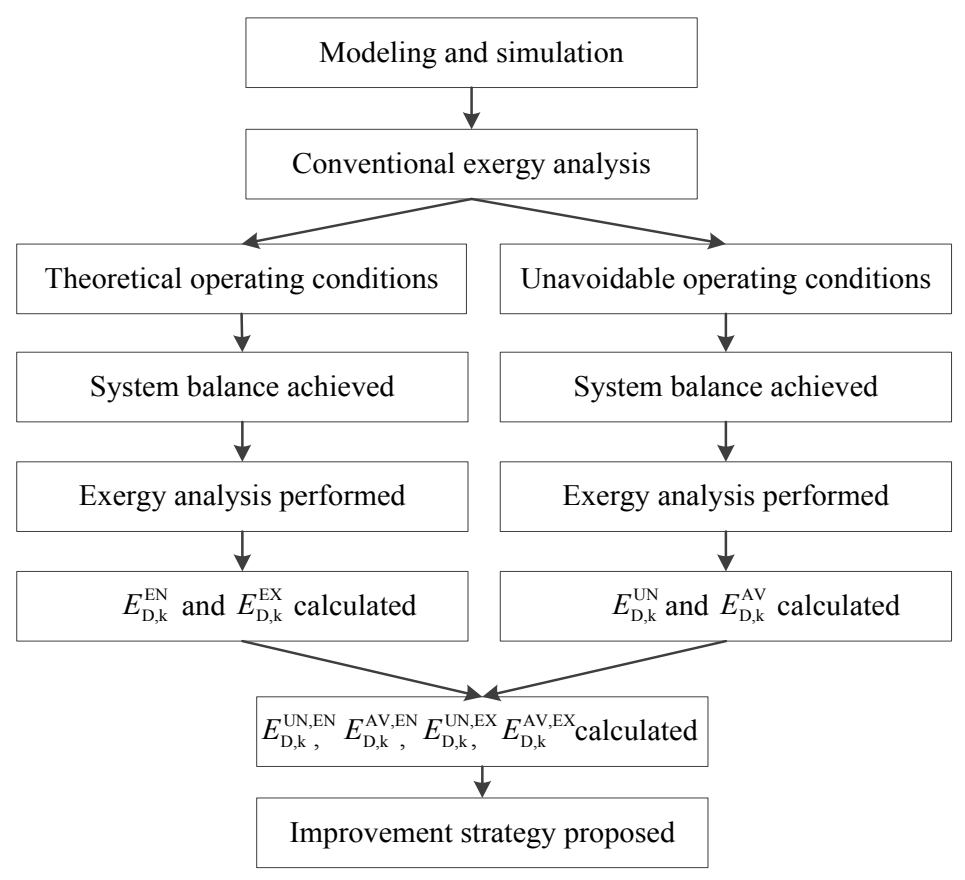

Fig. 3. Flow diagram of advanced exergy analysis of the FsOSR process 


\section{$1 \quad 3.1$ Process modeling and simulation}

Table 1 Proximate and element analysis of samples

\begin{tabular}{lccccccccc}
\hline & \multicolumn{4}{c}{ proximate analysis $\left(\right.$ wt. \%, ar) ${ }^{\text {a }}$} & \multicolumn{4}{c}{ element analysis $\left(\right.$ wt. \%, ar) ${ }^{\text {a }}$} \\
& M & FC & V & A & C & H & O & N & S \\
\hline oil shale & 5.00 & 3.69 & 18.56 & 72.79 & 79.07 & 9.93 & 7.02 & 2.12 & 1.86 \\
\hline semi-coke & 0.44 & 82.13 & 14.34 & 4.09 & 11.42 & 0.81 & 3.18 & 0.76 & 1.26 \\
\hline shale oil & & & & 85.39 & 12.09 & 0.71 & 1.27 & 0.54 \\
\hline a received basis. & & & & & & & &
\end{tabular}

Table 2 Key operating parameters required for the simulation

\begin{tabular}{llll}
\hline Key parameter & Value & Key parameter & Value \\
\hline Retorting temperature & $500^{\circ} \mathrm{C}$ & Collecting tube temperature & $86^{\circ} \mathrm{C}$ \\
Gasification temperature & $950^{\circ} \mathrm{C}$ & Washing tower temperature & $76^{\circ} \mathrm{C}$ \\
Operating pressure & $0.1 \mathrm{MPa}$ & Indirect cooling tower temperature & $42^{\circ} \mathrm{C}$ \\
Saturated air temperature & $83^{\circ} \mathrm{C}$ & Electric oil separator temperature & $40^{\circ} \mathrm{C}$ \\
Recycle gas temperature & $650^{\circ} \mathrm{C}$ & Heating furnace temperature & $1500^{\circ} \mathrm{C}$ \\
\hline
\end{tabular}

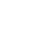

The following assumptions were made in modelling of the FsOSR process: (1) the whole system operates in steady state; (2) oil shale particles do not flow back to the retorting reactor; (3) organic material in the oil shale is completely reacted; (4) ash in the oil shale is considered as an inert material and does not take part in the retorting reaction; (5) hydrocarbons are represented by $\mathrm{CH}_{4}, \mathrm{C}_{2} \mathrm{H}_{4}, \mathrm{C}_{2} \mathrm{H}_{6}, \mathrm{C}_{3} \mathrm{H}_{6}$ and $\mathrm{C}_{3} \mathrm{H}_{8}$, as

1 the amount of other components is negligible; and (6) there is no pressure drop across 
1 the whole process [10].

2 The FsOSR process consists of two main parts: retorting and a separation unit.

3 The simulation flowsheet of this process is shown in Figure 4. After being crushed

4 and screened, oil shale enters the retorting stage of the process. The retorting stage is

5 modeled as a continuously stirred tank reactor. The gasification stage of the process is

6 modeled as a minimum Gibbs free energy reactor using the RGibbs model. In the

7 retorting stage, the oil shale is converted into shale oil, retorting gas and semi-coke at

$80.1 \mathrm{MPa}$ and $525^{\circ} \mathrm{C}$. For the purpose of the simulation, oil shale is defined as a

9 mixture of external water, organic matter (kerogen) and inorganic minerals. Inorganic

10 minerals do not take part in the decomposition reaction as only kerogen reacts. The

11 shale oil can be represented as $\mathrm{C}_{6} \mathrm{H}_{10}$ [29]. Thus, the oil shale retorting reaction is:

12 kerogen $\rightarrow \mathrm{C}_{6} \mathrm{H}_{10}+\mathrm{H}_{2}+\mathrm{H}_{2} \mathrm{O}+\mathrm{H}_{2} \mathrm{~S}+\mathrm{CO}+\mathrm{CO}_{2}+\mathrm{CH}_{4}+\mathrm{C}_{2} \mathrm{H}_{6}+\mathrm{C}_{3} \mathrm{H}_{8}+\mathrm{NH}_{3}+$ char

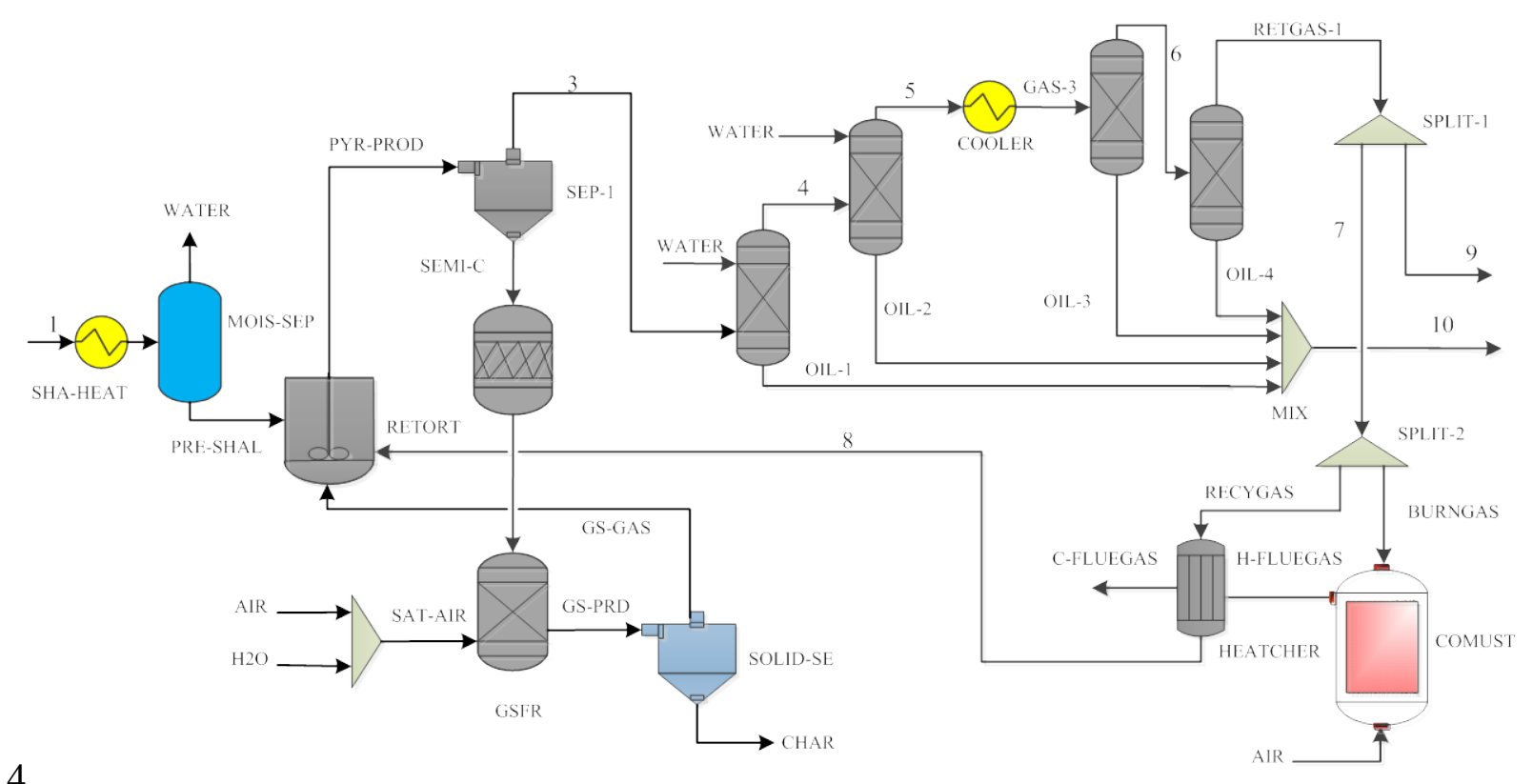

14

15

16

17 Many researchers have found that the oil shale kerogen retorting reaction is a

18 first order reaction [6]. Its kinetic equation is formulated as follows [32]: 
$1 \quad \frac{\mathrm{d} x}{\mathrm{~d} t}=k(1-x)^{n}=A \exp \left(-\frac{E_{a}}{\mathrm{R} T}\right)(1-x)^{n}$

2 where $x$ is concentration at a time $t, k$ is the specific rate constant, $n$ is the order of the

3 reaction, $A$ is the apparent frequency factor, $E_{\mathrm{a}}$ is the apparent activation energy, and

$4 \mathrm{R}$ is the gas constant equal to $8.314 \mathrm{~J} /(\mathrm{mol} \mathrm{K})$. For Fushun oil shale, the specific rate

5 constant $k$ is given as follows [33]:

6

$$
k=2.81 \times 10^{13} \exp \left(-\frac{26390}{T}\right)
$$

Equations (2) and (3) give:

$$
\frac{\mathrm{d} x}{\mathrm{~d} t}=k(1-x)^{n}=2.81 \times 10^{13} \exp \left(-\frac{26390}{T}\right)(1-x)
$$

The semi-coke produced in the retorting process is fed into the gasification stage. The semi-coke is reacted with saturated air at $0.1 \mathrm{MPa}$ and $950^{\circ} \mathrm{C}$. The following 11 reactions take place at this point: reduction, represented by Eqs. (5)-(7), and oxidation, 12 illustrated by Eqs (8)-(10). is recycled back to the retorting stage to supply heat for the retorting reaction. The

21 oil-gas mixture from the retort enters the collecting tube, washing tower, indirect 22 cooling tower and electric oil separator to separate shale oil and retorting gas. The 23 reactions taking place in the collecting tube and the washing tower are given by Eqs. 24 (11)-(19). The outlet stream is directed to the indirect cooling tower and the electric oil separator in order to recover the remaining share of shale oil. 


$$
\begin{array}{ll}
1 & 2 \mathrm{H}_{2} \mathrm{O} \leftrightarrow \mathrm{H}_{3} \mathrm{O}^{+}+\mathrm{OH}^{-} \\
2 & \mathrm{H}_{2} \mathrm{~S}+\mathrm{H}_{2} \mathrm{O} \leftrightarrow \mathrm{H}_{3} \mathrm{O}^{+}+\mathrm{HS}^{-} \\
3 & \mathrm{HS}-+\mathrm{H}_{2} \mathrm{O} \leftrightarrow \mathrm{H}_{3} \mathrm{O}^{+}+\mathrm{S}^{2-} \\
4 & \mathrm{CO}_{2}+\mathrm{H}_{2} \mathrm{O} \leftrightarrow \mathrm{H}_{3} \mathrm{O}^{+}+\mathrm{HCO}_{3}^{-} \\
5 & \mathrm{HCO}_{3}^{-}+\mathrm{H}_{2} \mathrm{O} \leftrightarrow \mathrm{H}_{3} \mathrm{O}^{+}+\mathrm{CO}_{3}{ }^{2-} \\
6 & \mathrm{NH}_{3}+\mathrm{H}_{2} \mathrm{O} \leftrightarrow \mathrm{NH}_{4}^{+}+\mathrm{OH}^{-} \\
7 & \mathrm{HCO}_{3}^{-}+\mathrm{NH}_{3} \leftrightarrow \mathrm{NH}_{2} \mathrm{COO}^{-}+\mathrm{H}_{2} \mathrm{O} \\
8 & \mathrm{SO}_{2}+\mathrm{H}_{2} \mathrm{O} \leftrightarrow \mathrm{H}_{3} \mathrm{O}^{+}+\mathrm{HSO}_{3}^{-} \\
9 & \mathrm{HSO}_{3}{ }^{-}+\mathrm{H}_{2} \mathrm{O} \leftrightarrow \mathrm{H}_{3} \mathrm{O}^{+}+\mathrm{SO}_{3}{ }^{2-}
\end{array}
$$

10 A part of the purified retorting gas, called recycle gas, is sent to the retort after

11 being heated to $650^{\circ} \mathrm{C}$ by the burning gas. The combustion reactions are modeled 12 applying the model of a stoichiometric reactor (RStoic model). With a sufficient 13 amount of air, $\mathrm{CO}, \mathrm{H}_{2}, \mathrm{CH}_{4}$ and $\mathrm{C}_{\mathrm{n}} \mathrm{H}_{\mathrm{m}}\left(\mathrm{C}_{2} \mathrm{H}_{4}, \mathrm{C}_{2} \mathrm{H}_{6}, \mathrm{C}_{3} \mathrm{H}_{6}\right.$, and $\left.\mathrm{C}_{3} \mathrm{H}_{8}\right)$ contained in the 14 retorting gas are oxidized into $\mathrm{CO}_{2}$ and $\mathrm{H}_{2} \mathrm{O}$, as shown by Eqs. (20)-(24). The high 15 temperature flue gas is discharged after exchanging heat with the recycled gas.

\subsection{Conventional exergy analysis}

The concept of exergy is based on the second law of thermodynamics and is 23 defined as the maximum possible work potential of a system [34]. For a steady-state 24 system, exergy of a stream (E) includes physical exergy $\left(E_{\mathrm{ph}}\right)$, chemical exergy $\left(E_{\mathrm{ch}}\right)$, 
1 and mixing exergy $\left(\Delta_{\text {mix }} E\right)$. They can be calculated as follows $[35,36]$ :

2

24 where the subscript tot means overall system. [38]:

$$
E_{F, k}=E_{P, k}+E_{D, k}
$$
the exergy destruction within the $\mathrm{k}^{\text {th }}$ component. can be written as [40]:

where $L$ and $V$ are the liquid and gas mole flow rates; $x_{i}$ and $y_{i}$ are the mole fraction of each substance $i ; h_{i}^{1}$ and $h_{i}^{\mathrm{v}}$ are the enthalpy of each substance $i$ in the liquid and gas phases; $s_{i}^{1}$ and $s_{i}^{\mathrm{v}}$ are the entropy of each substance $i$ in the liquid and gas phases; $E x_{\mathrm{ch}, \mathrm{i}}^{01}$ and $E x_{\mathrm{ch}, \mathrm{i}}^{0 \mathrm{v}}$ are the standard molar chemical exergy of substance $i$ in the liquid and gas phases; $\Delta_{m i x} h$ and $\Delta_{m i x} s$ are the mixing enthalpy and entropy, respectively; and 0 is the reference thermodynamic environment.

The exergy balance is used to calculate exergy destruction and to determine its distribution [37]. The exergy balance for the $\mathrm{k}^{\text {th }}$ component can be written as follows

where $E_{F, k}$ is the exergy of the fuel; $E_{P, k}$ is the exergy of the product; and $E_{D, k}$ is

There is no exergy loss associated with the $\mathrm{k}^{\text {th }}$ component based on an assumption that the system boundaries, used for analysis of exergy balances, are at the reference temperature $\mathrm{T}_{0}[39]$. Therefore, the exergy losses, $E_{\mathrm{L}}$, are considered only at the level of the overall system, and the exergy balance for the overall FsOSR system

$$
E_{F, t o t}=E_{P, t o t}+E_{\mathrm{D}, t o t}+E_{L, t o t}=E_{P, t o t}+\sum_{k} E_{D, k}+E_{L, t o t}
$$


1 In conventional exergy analysis, two variables are defined to evaluate system

2 performance:

3 1) Exergy efficiency $(\varepsilon)$ : the ratio of the exergy of the product and fuel. The $\mathrm{k}^{\text {th }}$

4 component $\varepsilon_{k}$ and the overall system $\varepsilon_{\text {tot }}$ are defined as [41]:

$5 \quad \varepsilon_{k}=\frac{E_{P, k}}{E_{F, k}} \times 100 \%$

$6 \quad \varepsilon_{k}=\frac{E_{P, \text { tot }}}{E_{F, t o t}} \times 100 \%$

7 2) Exergy destruction ratio $(y)$. For the $\mathrm{k}^{\text {th }}$ component, $y_{\mathrm{k}}$ is the ratio of the

8 exergy destruction within the $\mathrm{k}^{\text {th }}$ component to the total exergy of the fuel; $y_{k}^{*}$ is the

9 ratio of the exergy destruction within the $\mathrm{k}^{\text {th }}$ component to the total exergy destruction

10 of the system [42]. For the overall system, $y_{\text {tot }}$ is the ratio of the total system exergy

11 destruction to the total exergy of the fuel of the overall system. The ratios can be

12 calculated as [43]:

13

$$
y_{k}=\frac{E_{D, k}}{E_{F, t o t}} \times 100 \%
$$

$14 \quad y_{k}^{*}=\frac{E_{D, k}}{E_{\mathrm{D}, t o t}} \times 100 \%$

$$
y_{t o t}=\frac{E_{D, t o t}}{E_{F, t o t}} \times 100 \%
$$

\subsection{Advanced exergy analysis}

Conventional exergy analysis does not provide results for interactions between components nor provide information about the improvement potential of each

19 component of the system [16]. Advanced exergy analysis, however, evaluates the

20 interactions between the components, and reveals the potential for improving the

21 system component/the overall system within the given technological and economic 
1 constraints [20]. Advanced exergy analysis involves splitting the exergy destruction of

2 the system components into endogenous/exogenous and avoidable/unavoidable parts

3 [20]. By combining the two splitting options, exergy destruction can be separated into

4 four parts: unavoidable-endogenous, unavoidable-exogenous, avoidable-endogenous

5 and avoidable-exogenous exergy destruction.

Endogenous/exogenous exergy destruction: The exergy destruction within the

$7 \mathrm{k}^{\text {th }}$ component is the sum of the endogenous and exogenous exergy destruction, as 8 shown in Eq. (36) [25].

9

$$
E_{D, k}=E_{D, k}^{E N}+E_{D, k}^{E X}
$$

Endogenous exergy destruction $\left(E_{D, k}^{E N}\right)$ is the part of the exergy destruction within the $\mathrm{k}^{\text {th }}$ component obtained when all other components operate in ideal/reversible conditions and the $\mathrm{k}^{\text {th }}$ component under consideration operates with its currently efficiency. The exogenous part of the variable $\left(E_{D, k}^{E X}\right)$ is the share of exergy destruction within the $\mathrm{kt}^{\mathrm{h}}$ component reduced by a structural upgrading of the overall system or by increasing the efficiency of the remaining elements or by improving the efficiency of the $\mathrm{k}^{\text {th }}$ component [26].

\section{Unavoidable/avoidable exergy destruction: The unavoidable exergy} destruction $\left(E_{D, k}^{U N}\right)$ is the amount of exergy destruction that cannot be reduced because of technical or economical limitations such as the availability and cost of materials or the manufacturing methods used [26]. The avoidable exergy destruction $\left(E_{D, k}^{A V}\right)$ is the difference between the total exergy destruction and the unavoidable exergy destruction [23]. Thus, the division of the exergy destruction into unavoidable and avoidable parts in the $\mathrm{k}^{\text {th }}$ component can be expressed by Eq (37). The separation of the exergy destruction into avoidable and unavoidable parts provides a realistic measure of the potential for improving the thermodynamic efficiency of the components involved. Namely, for any component, the avoidable exergy destruction is the part that should be considered during the improvement procedure [44]. 
$1 \quad E_{D, k}=E_{D, k}^{U N}+E_{D, k}^{A V}$

2 Combination of the splitting: After division of the exergy destruction into the

3 different parts; namely, endogenous, exogenous, unavoidable and avoidable parts, the

4 next task is to evaluate how the different categories of exergy destruction can be

5 combined to provide meaningful information [45]. Thus four different parts of exergy

6 destruction can be presented as follows [26]:

7
1) Unavoidable endogenous exergy destruction $\left(E_{D, k}^{U N, E N}\right)$ - cannot be reduced because of technical or economical limitations of the $\mathrm{k}^{\text {th }}$ component.

2) Avoidable endogenous exergy destruction $\left(E_{D, k}^{A V, E N}\right)$ - can be reduced by improving the efficiency of the $\mathrm{k}^{\text {th }}$ component.

3) Unavoidable exogenous exergy destruction $\left(E_{D, k}^{U N, E X}\right)$ - cannot be reduced because of technical or economical limitations of the other components of the overall system.

4) Avoidable exogenous exergy destruction $\left(E_{D, k}^{A V, E X}\right)$ - can be reduced by a structural improvement of the overall system or by improving the efficiency of the remaining components or by improving the efficiency in the $\mathrm{k}^{\text {th }}$ component.

All options of splitting the exergy destruction within the $\mathrm{k}^{\text {th }}$ component are explicitly described in Fig. 5. The four splitting combinations can be calculated based on the product exergy of the $\mathrm{k}^{\text {th }}$ component $\left(E_{P, k}^{R}\right)[23]$ :

$$
E_{D, k}=E_{D, k}^{A V, E N}+E_{D, k}^{U N, E N}+E_{D, k}^{A V, E X}+E_{D, k}^{U N, E X}
$$

$$
E_{D, k}^{U N}=E_{P, k}^{R} \times\left(\frac{E_{D}}{E_{P}}\right)_{k}^{U N}
$$

$$
E_{D, k}^{A V}=E_{D, k}-E_{D, k}^{U N}
$$




$$
E_{D, k}^{U N, E N}=E_{P, k}^{E N} \times\left(\frac{E_{D}}{E_{P}}\right)_{k}^{U N}
$$

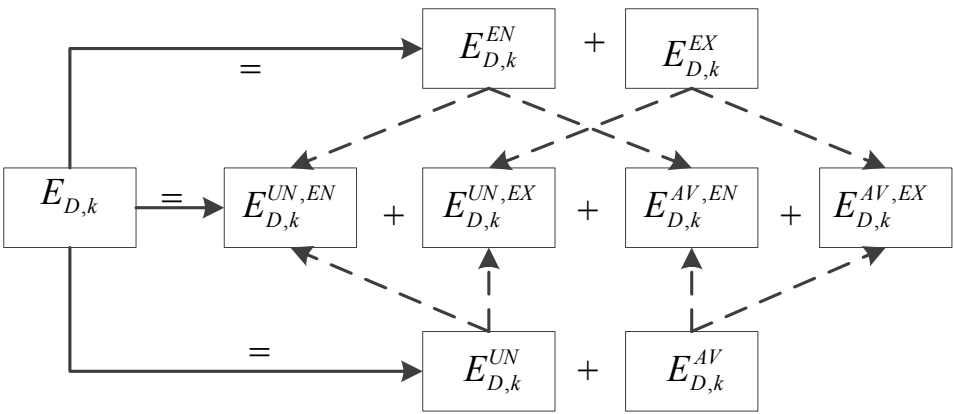

Fig. 5. Division of the exergy destruction in an advanced exergy analysis [43]

\section{Results and discussion}

Detailed conventional and advanced exergy analyses of FsOSR process were performed using the above-presented four-step method.

\subsection{Process simulation}

The simulation of the FsOSR process gives values for the key parameters of the main streams as shown in Table 3. The results show that about $21.90 \mathrm{t} / \mathrm{h}$ of shale oil can be produced from $500 \mathrm{t} / \mathrm{h}$ oil shale. The results of the simulation show that the shale oil recovery ratio is $74.97 \%$. This could be considered a quite satisfactory result when compared to industrial data, where the recovery ratios are in the range of $65-75 \%$ [1]. The composition of the retorting gas, as well as mass and energy balance results were compared with industrial data from the Fushun retorting plant in order to validate the accuracy of the model, shown in Tables 4-6. 
Table 3 Key parameters of the main streams of the FsOSR process

\begin{tabular}{lrrrrrrrrrr}
\hline NO. $^{\text {a }}$ & 1 & $2^{\mathrm{b}}$ & 3 & 4 & 5 & 6 & 7 & 8 & 9 & 10 \\
\hline $\mathrm{T}\left({ }^{\circ} \mathrm{C}\right)$ & 25 & - & 100 & 86 & 76 & 40 & 40 & 650 & 40 & 25 \\
mass $(\mathrm{t} / \mathrm{h})$ & 500.00 & 460.10 & 501.00 & 483.95 & 410.60 & 331.40 & 238.38 & 161.90 & 63.72 & 21.90 \\
exergy (MW) & 773.61 & 239.22 & 749.28 & 591.86 & 488.70 & 458.04 & 286.72 & 217.45 & 104.25 & 241.81 \\
mass fraction (\%) & & & & & & & & & & \\
$\mathrm{N}_{2}$ & 0.00 & 52.26 & 34.29 & 35.50 & 41.84 & 51.83 & 52.80 & 52.80 & 52.80 & 0.00 \\
$\mathrm{O}_{2}$ & 0.00 & 7.94 & 0.29 & 0.30 & 0.35 & 0.43 & 0.44 & 0.44 & 0.44 & 0.00 \\
$\mathrm{H}_{2}$ & 0.00 & 0.42 & 0.53 & 0.55 & 0.65 & 0.80 & 0.82 & 0.82 & 0.82 & 0.00 \\
$\mathrm{CO}^{2}$ & 0.00 & 2.25 & 2.84 & 2.94 & 3.47 & 4.29 & 4.37 & 4.37 & 4.37 & 0.00 \\
$\mathrm{CO}_{2}$ & 0.00 & 16.14 & 20.40 & 21.11 & 24.89 & 30.83 & 31.41 & 31.41 & 31.41 & 0.00 \\
$\mathrm{CH}_{4}$ & 0.00 & 1.89 & 2.39 & 2.47 & 2.92 & 3.61 & 3.68 & 3.68 & 3.68 & 0.00 \\
$\mathrm{C}_{2} \mathrm{H}_{6}$ & 0.00 & 0.35 & 0.45 & 0.46 & 0.55 & 0.68 & 0.69 & 0.69 & 0.69 & 0.00 \\
$\mathrm{C}_{3} \mathrm{H}_{8}$ & 0.00 & 0.51 & 0.65 & 0.67 & 0.79 & 0.98 & 1.00 & 1.00 & 1.00 & 0.00 \\
$\mathrm{H}_{2} \mathrm{O}$ & 0.00 & 18.23 & 31.68 & 32.69 & 22.76 & 4.66 & 4.75 & 4.75 & 4.75 & 0.00 \\
$\mathrm{NH}_{3}$ & 0.00 & 0.00 & 0.49 & 0.09 & 0.00 & 0.00 & 0.00 & 0.00 & 0.00 & 0.00 \\
$\mathrm{H}_{2} \mathrm{~S}$ & 0.00 & 0.00 & 0.15 & 0.05 & 0.00 & 0.00 & 0.00 & 0.00 & 0.00 & 0.00 \\
shale oil & 0.00 & 0.00 & 5.86 & 3.16 & 1.80 & 1.87 & 0.05 & 0.03 & 0.05 & 100.0 \\
oil shale & 100.0 & 0.00 & 0.00 & 0.00 & 0.00 & 0.00 & 0.00 & 0.00 & 0.00 & 0.00 \\
\hline
\end{tabular}

11 steady state of the system. Leakage and residuals in the industrial equipment are likely

12 to be bigger than those assumed in the simulation, resulting in a smaller production

13 yield and greater mass and energy losses. Additionally, for the sake of the model

14 simplicity, assumptions and simplifications have been made, as listed in Section 3.1. 
Table 4 Simulation and industrial data of the composition of the retorting gas

\begin{tabular}{llllllll}
\hline & \multicolumn{7}{c}{ Mole franction ${ }^{\mathrm{a}}(\%)$} \\
\cline { 2 - 8 } & $\mathrm{N}_{2}$ & $\mathrm{O}_{2}$ & $\mathrm{H}_{2}$ & $\mathrm{CO}$ & $\mathrm{CO}_{2}$ & $\mathrm{CH}_{4}$ & $\mathrm{C}_{\mathrm{n}} \mathrm{H}_{\mathrm{m}}{ }^{\mathrm{b}}$ \\
\hline Simulation data & 54.92 & 0.40 & 11.91 & 4.55 & 20.79 & 6.70 & 0.73 \\
Industrial data $^{[14]}$ & 54.91 & 0.40 & 11.90 & 4.43 & 20.84 & 6.77 & 0.75 \\
\hline
\end{tabular}

a: ignore the component with the fraction less than $1 \mathrm{PPM}$, such as $\mathrm{H}_{2} \mathrm{~S}$ and $\mathrm{NO}$.

b: $\mathrm{C}_{\mathrm{n}} \mathrm{H}_{\mathrm{m}}$ includes $\mathrm{C}_{2} \mathrm{H}_{4}, \mathrm{C}_{2} \mathrm{H}_{6}, \mathrm{C}_{3} \mathrm{H}_{8}, \mathrm{C}_{4} \mathrm{H}_{10}$, etc.

Table 5 Simulation and industrial data of the mass balance of the FsOSR process

\begin{tabular}{|c|c|c|c|c|c|c|}
\hline & & \multicolumn{2}{|c|}{ Simulation data } & \multicolumn{2}{|c|}{ Industrial data ${ }^{[9,14]}$} & \multirow{2}{*}{$R E(\%)^{\mathrm{a}}$} \\
\hline & & Mass $(\mathrm{t} / \mathrm{h})$ & Ratio (\%) & Mass $(\mathrm{t} / \mathrm{h})$ & Ratio (\%) & \\
\hline \multirow[t]{7}{*}{ Input } & Oil shale & 500.00 & 52.08 & 500.00 & 52.02 & 0.00 \\
\hline & Air & 110.05 & 11.46 & 111.50 & 11.60 & 1.30 \\
\hline & Water in air & 52.25 & 5.44 & 51.57 & 5.37 & 1.32 \\
\hline & Recycle gas & 161.90 & 16.86 & 157.35 & 16.37 & 2.89 \\
\hline & Water in recycle gas & 8.10 & 0.84 & 7.78 & 0.81 & 4.13 \\
\hline & Water & 127.80 & 13.31 & 132.94 & 13.83 & 3.86 \\
\hline & total & 960.10 & 100.00 & 961.14 & 100.00 & 0.11 \\
\hline \multirow[t]{9}{*}{ Output } & Output gas of retort & 146.97 & 15.31 & 145.87 & 15.18 & 0.75 \\
\hline & Water in output gas & 158.70 & 16.53 & 160.92 & 16.74 & 1.38 \\
\hline & Shale oil & 21.90 & 2.28 & 20.64 & 2.15 & 6.10 \\
\hline & Dry ash & 402.67 & 41.94 & 405.78 & 42.22 & 0.77 \\
\hline & Water in ash & 50.50 & 5.26 & 52.83 & 5.50 & 4.41 \\
\hline & Recycle gas & 161.90 & 16.86 & 157.35 & 16.37 & 2.89 \\
\hline & Water in recycle gas & 8.10 & 0.84 & 7.78 & 0.81 & 4.13 \\
\hline & Other/loss & 9.36 & 0.97 & 9.97 & 1.04 & 6.12 \\
\hline & Total & 960.10 & 100.00 & 961.14 & 100.00 & 0.11 \\
\hline
\end{tabular}


Table 6 Simulation and industrial data of the energy balance of the FsOSR process

\begin{tabular}{llrrrrr}
\hline & & \multicolumn{3}{c}{ Simulation data } & \multicolumn{3}{c}{ Industrial data ${ }^{[9,14]}$} & \multirow{2}{*}{$R E(\%)^{\mathrm{a}}$} \\
\cline { 3 - 6 } Input & Energy (MW) & Ratio (\%) & Energy (MW) & Ratio (\%) & \\
& Oil shale & 770.72 & 71.73 & 770.72 & 72.39 & 0.00 \\
& Air & 3.34 & 0.31 & 3.38 & 0.32 & 1.29 \\
& Water in air & 23.63 & 2.20 & 23.30 & 2.19 & 1.42 \\
& Recycle gas & 228.89 & 21.30 & 220.81 & 20.74 & 3.66 \\
& Water & 2.43 & 0.23 & 2.52 & 0.24 & 3.72 \\
& Total & 1029.01 & 95.77 & 1020.74 & 95.87 & 0.81 \\
Output & 288.32 & 26.83 & 289.83 & 27.22 & 0.52 \\
& Retorting gas & 146.25 & 13.61 & 148.77 & 13.97 & 1.69 \\
& Steam & 248.02 & 23.08 & 234.75 & 22.05 & 5.65 \\
& Shale oil & 89.21 & 8.30 & 93.73 & 8.80 & 4.82 \\
& Ash & 228.89 & 21.30 & 220.81 & 20.74 & 3.66 \\
& Recycle gas & 10.91 & 1.02 & 11.73 & 1.10 & 6.99 \\
Waste water & 17.41 & 1.62 & 21.12 & 1.98 & 17.57 \\
& Other/loss & 1029.01 & 95.77 & 1020.74 & 95.87 & 0.81 \\
\hline Total & &
\end{tabular}

4 In summary, the simulation results show that the obtained values of the 5 composition of the retorting gas as well as the mass and the energy balances are 6 reasonably consistent with industrial data.

\section{$7 \quad 4.2$ Conventional analysis of exergy}

8 Based on the low heating value of oil shale $\left(\Delta h_{\mathrm{L}}^{\theta}\right)$ and the high heating value of

9 shale oil $\left(\Delta h_{\mathrm{H}}^{\theta}\right)$, the standard exergies of oil shale and shale oil are formulated as

10 follows [15]:

$11 \quad e_{\mathrm{os}}^{\theta}=\Delta h_{\mathrm{L}}^{\theta}+2438 \times \omega$

$12 e_{\mathrm{so}}^{\theta}=0.975 \times \Delta h_{\mathrm{H}}^{\theta}$

13 where $e_{\mathrm{os}}^{\theta}$ is the standard exergy of oil shale, $\mathrm{kJ} / \mathrm{kg} ; \Delta h_{\mathrm{L}}^{\theta}$ is the low heating value of 14 oil shale, $\mathrm{kJ} / \mathrm{kg} ; 2438 \mathrm{~kJ} / \mathrm{kg}$ is the amount of heat needed for water vaporization; $\omega$ is 
1 the mass fraction of water in oil shale, $\% ; e_{\mathrm{so}}^{\theta}$ is standard exergy of shale oil, $\mathrm{kJ} / \mathrm{kg}$;

2 and $\Delta h_{\mathrm{H}}^{\theta}$ is the high heating value of shale oil, $\mathrm{kJ} / \mathrm{kg}$.

3 Based on the exergy balance, a detailed conventional exergy analysis was 4 performed, the results of which are shown in Table 7. The total exergy input of the 5 FsOSR process is $1012.83 \mathrm{MW}$. The exergy of the products is $346.06 \mathrm{MW}$. Thus, the 6 exergy efficiency of the whole process is $34.17 \%$. It is clear from Table 7 that $26.02 \%$ 7 of the total input exergy of the fuel is destroyed in the retort as a result of the oil shale 8 retorting and semi-coke gasification reactions conducted at high temperature. The 9 heating furnace has relatively large exergy destruction due to gas combustion and heat 10 transfer at high temperature difference. The collecting tube, the washing tower, the 11 indirect cooling tower, and the electric oil separator cause much smaller exergy 12 destruction. In these components, temperature drop, leading to a fall in the quality of 13 the energy, is the major cause of the exergy destruction.

Table 7 Results of conventional exergy analysis of the FsOSR process

\begin{tabular}{lrrrrrr}
\hline & $E_{\mathrm{F}, \mathrm{k}}(\mathrm{MW})$ & $E_{\mathrm{P}, \mathrm{k}}(\mathrm{MW})$ & $E_{\mathrm{D}, \mathrm{k}}(\mathrm{MW})$ & $\varepsilon_{\mathrm{k}}(\%)$ & $y_{\mathrm{k}}(\%)$ & $y_{k}^{*}(\%)$ \\
\hline retort & 1012.83 & 749.28 & 263.55 & 73.98 & 26.02 & 59.54 \\
collecting tube & 749.28 & 708.22 & 41.07 & 94.52 & 4.05 & 9.28 \\
washing tower & 591.86 & 561.21 & 30.66 & 94.82 & 3.03 & 6.93 \\
indirect cooling tower & 488.70 & 467.57 & 21.13 & 95.68 & 2.09 & 4.77 \\
electric oil separator & 458.04 & 441.10 & 16.94 & 96.30 & 1.67 & 3.83 \\
heating furnace & 286.72 & 217.45 & 69.27 & 75.84 & 6.84 & 15.65 \\
overall system & 1012.83 & 346.06 & 442.62 & 34.17 & 43.70 & 100.00 \\
\hline
\end{tabular}

$16 \quad 4.3$ Advanced analysis of exergy

17 The advanced exergy analysis model of the FsOSR process is formulated as 18 shown in Fig. 6. $E_{\mathrm{F}, \text { tot }}, E_{\mathrm{P}, \text { tot }}$ and $E_{D, t o t}$ of the FsOSR process are as follows:

$$
\begin{aligned}
& E_{\mathrm{F}, \text { tot }}=E_{\mathrm{F}, \mathrm{R}}=E_{\mathrm{F}, \text { oil shale }}+E_{\mathrm{F}, \text { air }}+E_{\mathrm{F}, \text { water }}+E_{\mathrm{F}, \text { recycle gas }} \\
& E_{\mathrm{P}, \text { tot }}=E_{\mathrm{P}, \mathrm{OC}}+E_{\mathrm{P}, \mathrm{OW}}+E_{\mathrm{P}, \mathrm{OI}}+E_{\mathrm{P}, \mathrm{OE}}+E_{\mathrm{P}, \mathrm{RE}}+E_{\mathrm{P}, \mathrm{H}}
\end{aligned}
$$


2 where $E_{\mathrm{D}, \mathrm{R}}, E_{\mathrm{D}, \mathrm{C}}, E_{\mathrm{D}, \mathrm{W}}, E_{\mathrm{D}, \mathrm{I}}, E_{\mathrm{D}, \mathrm{E}}$, and $E_{\mathrm{D}, \mathrm{H}}$ are the exergy destruction of the

3 retort, collecting tube, washing tower, indirect cooling tower, electric oil separator,

4 and heating furnace, respectively; $E_{\mathrm{P}, \mathrm{OC}}, E_{\mathrm{P}, \mathrm{OW}}, E_{\mathrm{P}, \mathrm{OI}}$, and $E_{\mathrm{P}, \mathrm{OE}}$ are the shale oil

5 product exergies of the collecting tube, washing tower, indirect cooling tower, and

6 electric oil separator, respectively; $E_{\mathrm{P}, \mathrm{RE}}$ is the remaining gas exergy; and $E_{\mathrm{P}, \mathrm{H}}$ is the

7 product exergy of the heating furnace.

8

9

10

11

12 During system operation, the exergetic value of the product, $E_{\mathrm{P} \text {,tot }}$, is constant.

13 The results of the advanced exergy analysis of the FsOSR process are shown in Table 148 .

15

\begin{tabular}{lrrrrrrrr}
\hline$E_{D, k}(\mathrm{MW})$ & $E_{D, k}^{E N}$ & $E_{D, k}^{E X}$ & $E_{D, k}^{U N}$ & $E_{D, k}^{A V}$ & $E_{D, k}^{U N, E N}$ & $E_{D, k}^{A V, E N}$ & $E_{D, k}^{U N, E X}$ & $E_{D, k}^{A V, E X}$ \\
\hline retort & 198.21 & 65.34 & 114.67 & 148.88 & 99.45 & 98.76 & 15.22 & 50.12 \\
collecting tube & 32.67 & 8.4 & 25.99 & 15.08 & 23.48 & 9.19 & 2.51 & 5.89 \\
washing tower & 24.43 & 6.23 & 15.22 & 15.43 & 13.83 & 10.6 & 1.39 & 4.84 \\
indirect cooling tower & 17.24 & 3.89 & 12.8 & 8.33 & 11.81 & 5.43 & 0.99 & 2.9 \\
electric oil separator & 14.29 & 2.65 & 8.08 & 8.86 & 7.59 & 6.7 & 0.49 & 2.16 \\
heating furnace & 69.27 & - & 24.16 & 45.11 & 24.16 & 45.11 & - & - \\
overall system & 356.11 & 86.51 & 200.93 & 241.69 & 180.32 & 175.79 & 20.6 & 65.91 \\
\hline
\end{tabular}

16

17 Endogenous/Exogenous exergy destruction: Table 8 shows that a large part of

18 the exergy destruction in all components of the system is endogenous. The proportion 
1 of endogenous exergy destruction differs significantly for the various components.

2 For example, the endogenous exergy destruction of the retort and the heating furnace 3 is $75.21 \%$ and $100 \%$ respectively. The results also show that all exogenous exergy 4 destruction, except in the heating furnace, is positive, which means that the

5 performance of any component can be improved by performance enhancement of the 6 other components of the system.

Unavoidable/Avoidable exergy destruction: Constraints defining practically

8 feasible operation conditions, i.e. unavoidable conditions, were determined based on 9 the knowledge and experience of the authors. This was done by assessing the 10 realistically feasible potential for improvements that could be achieved for each 11 component in the foreseeable future [24, 25]. Energy consumption and exergy 12 destruction in equipment such as the compressor decreases as its efficiency improves. 13 Naturally, this will contribute to performance improvement of the whole system, but 14 simultaneously it will generate higher capital costs. Thus, the efficiency of the 15 components can be improved only to a certain level because of technical constraints 16 and economic constraints [18]. In this paper, the unavoidable conditions of the $\mathrm{k}^{\text {th }}$ 17 component are assumed as follows [7, 15]: $\varepsilon_{R}=85 \%, \varepsilon_{C}=96 \%, \varepsilon_{W}=97 \%, \varepsilon_{I}$ $18=97 \%, \varepsilon_{E}=98 \%$, and $\varepsilon_{H}=90 \%$. Table 8 shows that unavoidable exergy destruction 19 for each component and the whole system is not equal to zero. This means that the 20 real potential for improvement of the system's components is not determined by its 21 total exergy destruction but by its avoidable parts. The avoidable exergy destruction 22 of the retort and the heating furnace are $56.50 \%$ and $65.12 \%$, showing the largest 23 improvement potential. Consequently, these parts of the system should be the focus of 24 efforts to improve the FsOSR process. The avoidable exergy destruction of the 25 remaining components is higher than $36 \%$, also giving room for improvement.

26 Combined analysis: The retort has the largest avoidable endogenous exergy 27 destruction, followed by the heating furnace, and the washing tower. The retort also 
1 has the largest avoidable exogenous exergy destruction $\left(E_{D, k}^{A V, E X}\right)$, followed by the

2 collecting tube and the washing tower. The $E_{D, k}^{A V, E X}$ of the retort, collecting tube,

3 washing tower, indirect cooling tower, and electric separator is higher than zero. This

4 indicates that in order to reduce one of the above five components' exergy destruction

5 should focus on improving the other components' performances. However, $E_{D, k}^{A V, E X}$ of

6 the heating furnace is zero because that the $E_{D, k}^{E X}$ of the heating furnace is zero.

7 Consequently, the performance of the other components in the system has no

8 influence on the heating furnace. To diminish the exergy destruction of the heating

9 furnace, efforts should be exclusively concentrated on reducing the avoidable 10 endogenous exergy destruction in the heating furnace itself.

\section{$11 \quad 4.4$ Comparison of conventional and advanced exergy analysis}

The concepts of exergy destruction $\left(E_{\mathrm{D}, \mathrm{k}}\right)$ and exergy destruction ratio $(y)$ are 13 used for conducting conventional exergy analysis. The advanced exergy analysis is 14 based on division of exergy destruction into two main groups: endogenous/exogenous 15 exergy destruction and avoidable/unavoidable exergy destruction. The advanced 16 exergy analysis has the following advantages in comparison to the conventional ones:

17 (1) The advanced exergy analysis can identify the share of the exergy destruction 18 that can be avoided. The conventional exergy analysis indicates only that the total 19 exergy destruction of the FsOSR process is $442.62 \mathrm{MW}$. The results obtained from 20 splitting the $E_{\mathrm{D}, \mathrm{k}}$ into its unavoidable $\left(E_{D, k}^{U N}\right)$ and avoidable $\left(E_{D, k}^{A V}\right)$ parts show that $2145.40 \%$ of the exergy destruction is unavoidable and cannot be reduced as shown in $22 \quad$ Fig. 7.

23 (2) The advanced exergy analysis can determine the interactions between the 24 components of the system. The results obtained from splitting the $E_{\mathrm{D}, \mathrm{k}}$ into its 25 endogenous $\left(E_{D, k}^{E N}\right)$ and exogenous $\left(E_{D, k}^{E X}\right)$ parts show that $19.54 \%$ of the exergy 
1 destruction is caused by the interactions between the components of the FsOSR 2 process as shown in Fig. 7.

(3) The advanced exergy analysis can identify the improvement potential of each

4 component. The improvement potential of each component can be determined on the

5 basis of avoidable-endogenous $\left(E_{D, k}^{A V, E N}\right)$ and avoidable-exogenous $\left(E_{D, k}^{A V, E X}\right)$ exergy

6 destruction. The highest priority should be given to the retort, followed by the heating 7 furnace and the washing tower as shown in Table 8, section 4.3. The indirect cooling 8 tower and the electric oil separator have the lowest priority for improvement.

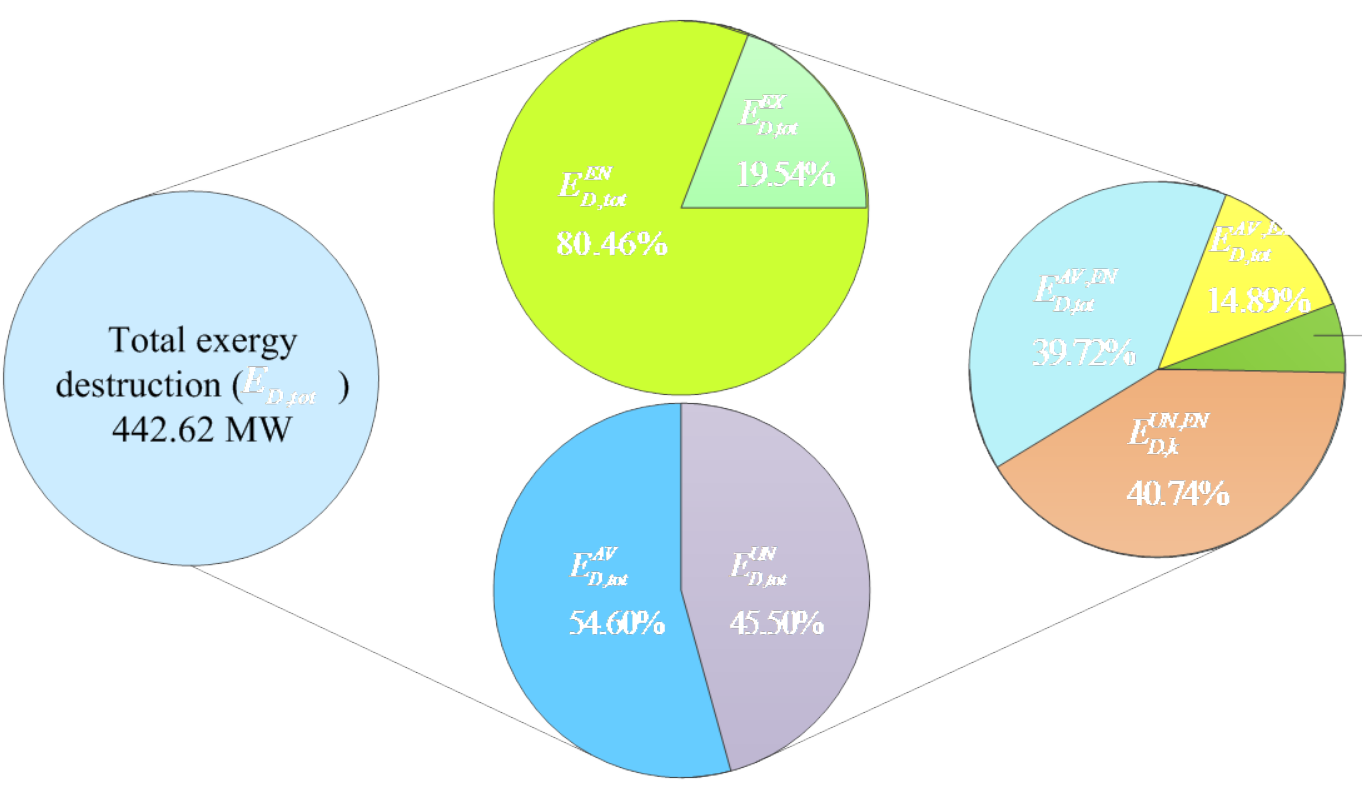

Fig.7. Division of total exergy destruction of the FsOSR process

\subsection{Improvement strategy}

Based on the results discussed above, the retort has the largest avoidable exergy destruction. Special attention should be paid to improvement of the operation of the retort when aiming to improve the overall performance of the FsOSR process. As shown in Table 8, the endogenous exergy destruction and exogenous exergy destruction of the retort are large and roughly equal. Therefore, improvement in the performance of the retort could be achieved by: 
1 retort is mainly caused by the other components in the system, such as the collecting

2 tube (C), washing tower (W), indirect cooling tower (I), electric separator (E), and

3 heating furnace $(\mathrm{H})$. In this paper, we study the effect of unavoidable exergy

4 efficiency of the remaining components on the $E_{D, k}^{A V}$ of the retort as shown in Fig.8.

5 The avoidable exergy destruction of the retort rises as the unavoidable exergy

6 efficiencies of the other components increase. The collecting tube has the largest

7 influence on possible reduction of the exogenous exergy destruction of the retort,

8 followed by the washing tower. The heating furnace has relatively small influence,

9 mainly because of the large impact of the collecting tube and retort resulting from

10 their very close proximity. However, as the unavoidable exergy efficiency of the

11 components increase, then the equipment cost would also raise slightly.

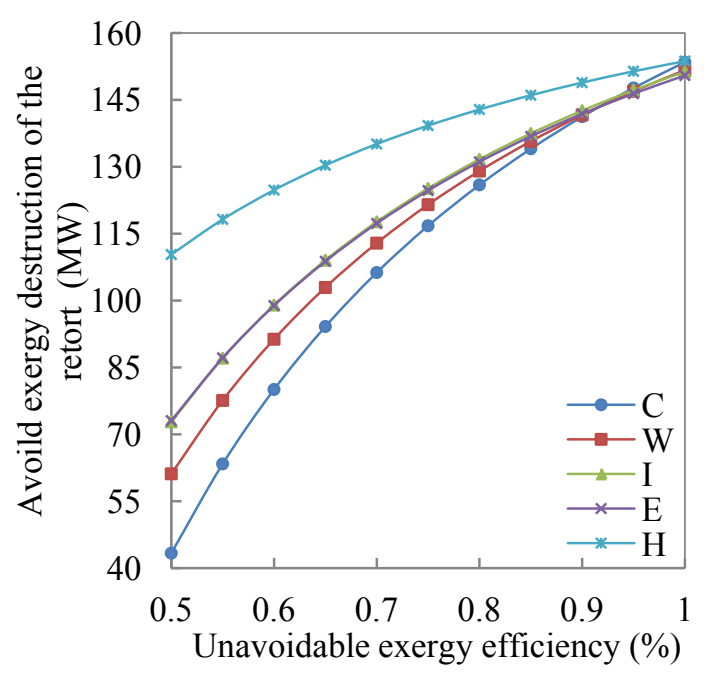

Fig.8. Relationship of $E_{D, R}^{A V}$ and the unavoidable exergy efficiency of the other components

Reducing endogenous exergy destruction: For the sake of reducing the

17 endogenous exergy destruction of the retort, one of effective ways is to optimize its 18 key operational parameters. The temperatures of the retorting and the feeding air have 19 a great impact on production of the shale oil and the retorting gas [46, 47]. As a result, 20 they affect the endogenous exergy destruction of the retort.

21 (1) Effect of retorting temperature on reduction of endogenous exergy 
1 destruction. In the temperature range between $420^{\circ} \mathrm{C}$ and $520^{\circ} \mathrm{C}$, the total exergy

2 destruction and the avoidable exergy destruction of the retort are greatly reduced,

3 while the unavoidable exergy destruction increases as shown in Fig. 9. This is caused

4 by the fact that the decomposition rate of oil shale increases quickly in this range of

5 temperatures and increasingly more oil shale is completely converted into shale oil

6 and retorting gas. This increases the irreversibility of the retorting reaction, resulting

7 in a gradual increase of exergy destruction. When the temperature is higher than

$8520^{\circ} \mathrm{C}$, there is no big change in the total exergy and the avoidable exergy destruction

9 of the retort because only a small amount of the remaining organics can be

10 decomposed at this temperature range. Consequently, there is no big improvement

11 potential when the temperature rises higher than $520^{\circ} \mathrm{C}$. In light of the above analysis,

12 the suggested temperature for operation of the retort is $520^{\circ} \mathrm{C}$.

14

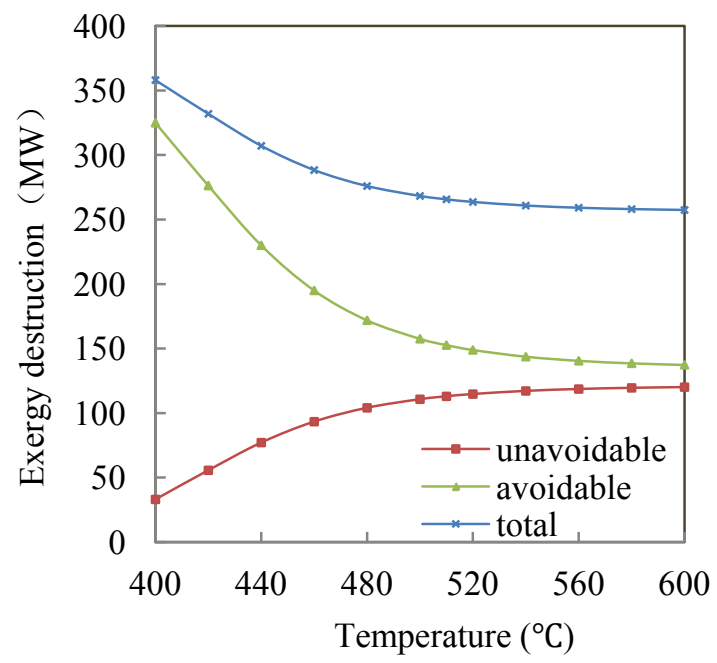

Fig.9. Effect of the retorting temperature on the exergy destruction of the retort

(2) Effect of temperature of feeding air on reduction of endogenous exergy destruction. In Chinese oil shale industry, the temperature of the feeding air is called as the saturation of the feeding air. It is explained by the fact that the fraction of steam in the feeding air depends mainly on its temperature. The steam in the feeding air acts not only as the gasification agent, but it is also a carrier providing heat for the 
1 retorting stage [14]. The effect of the temperature of feeding air on the endogenous

2 exergy destruction is shown in Fig. 10. An increase in the temperature is accompanied

3 by a decrease in the total exergy destruction and avoidable exergy destruction of the

4 retort. At the same time, the unavoidable exergy destruction increases. The avoidable

5 and unavoidable exergy destructions of the retort fall or rise significantly when the

6 temperature is higher than $60^{\circ} \mathrm{C}$. It is a result of the change in the partial pressure of

7 the steam, which has a great impact on the other parameters of the retort. Thus, high

8 temperature of the feeding air reduces the endogenous exergy destruction. The

9 suggested temperature of the feeding air should be to $90^{\circ} \mathrm{C}$.

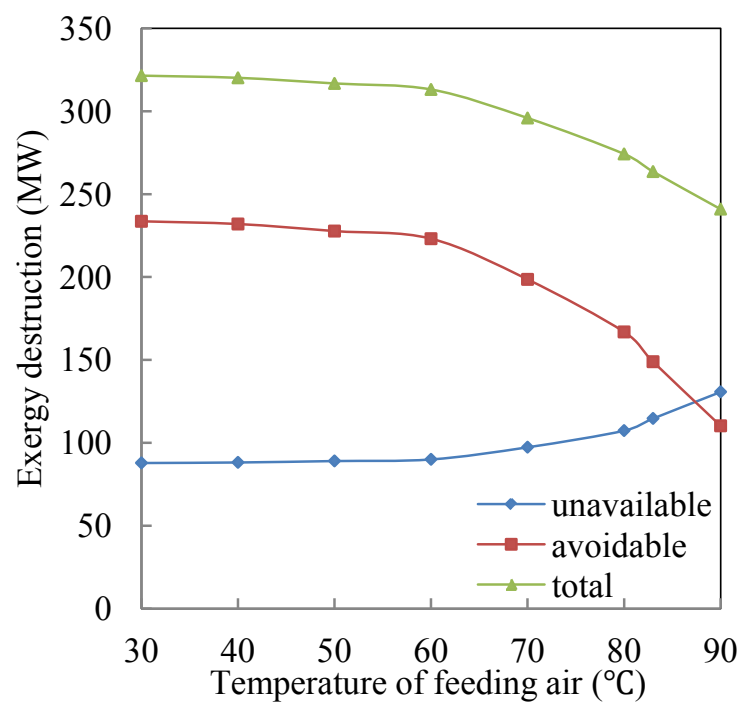

Fig.10. Effect of the temperature of feeding air on the exergy destruction of the retort

(1)

For the purpose of this analysis, the existing Fushun oil shale utilization plant is a reference system. To demonstrate the advantages of the proposed improvement strategies, the obtained results were compared to the characteristics of base system, Fig. 11. When comparing the reference and the improved systems it is seen that the retorting temperature increases from $500^{\circ} \mathrm{C}$ to $520^{\circ} \mathrm{C}$ and that of feeding air from $83^{\circ} \mathrm{O}$ o $90^{\circ} \mathrm{C}$. As the results show, the total exergy destruction of the improved system decreases from 263.55 MW to $238.91 \mathrm{MW}$; the avoidable exergy destruction is decreased from 148.88 MW to 107.20 MW; while the unavoidable exergy is increased 
1 from 114.67 MW to $131.71 \mathrm{MW}$. It is mainly caused by the fact that more oil shale is

2 completely converted into shale oil and retorting gas as the value of the above

3 mentioned parameters increase. Moreover, retorting and gasification reactions

4 increase the irreversiblities of the system, leading in consequence to the growth of

5 unavoidable exergy destruction. Because the production of shale oil and retorting gas

6 is growing, the profitability of the FsOSR process increases. As a result, the economic

7 performance of the process could be improved. A more detailed economic/

8 exergoeconomic analysis will be conducted in a forthcoming paper.

9

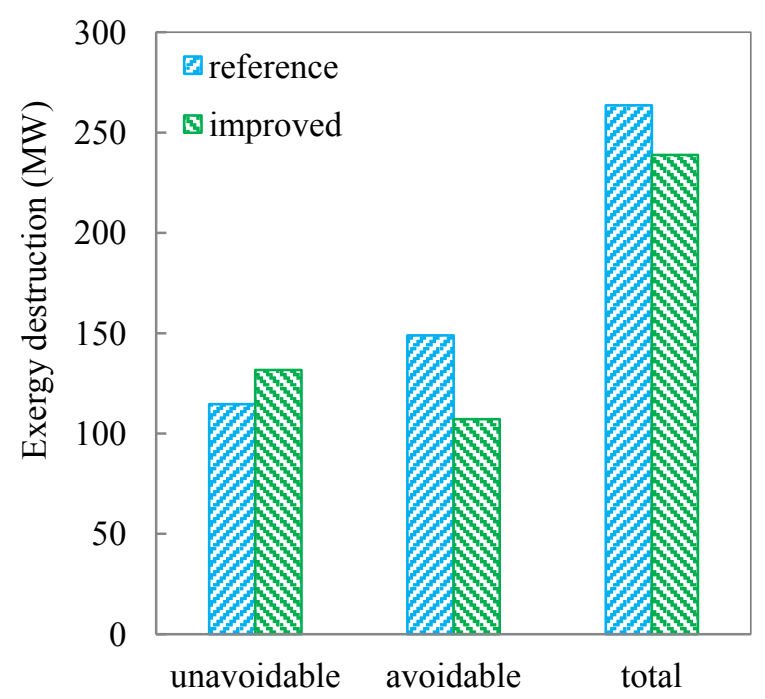

Fig.11. Comparison of the exergy destruction of the reference and improved systems

12

\section{Conclusions}

In this paper, conventional and advanced exergy analyses were applied to evaluate the performance of a Fushun-type oil shale retorting process (FsOSR). The process was modeled and simulated to calculate and analyze its mass and energy balance. The simulation results were validated by comparison with industrial data. The following conclusions are drawn:

1. The model of the system proposed in this paper is accurate, as illustrated by comparison of the results of the process simulation and the industrial data. About 
$121.90 \mathrm{t} / \mathrm{h}$ of shale oil can be produced from $500 \mathrm{t} / \mathrm{h}$ oil shale.

2 2. The exergy efficiency of the FsOSR process based on conventional exergy

$19 e_{\mathrm{os}}^{\theta} \quad$ standard exergy of oil shale, $\mathrm{kJ} / \mathrm{kg}$

$20 e_{\mathrm{so}}^{\theta} \quad$ standard exergy of shale oil, $\mathrm{kJ} / \mathrm{kg}$

21 FsOSR Fushun-type oil shale retorting

$22 h$ enthalpy, $\mathrm{kJ} / \mathrm{mol}$

$23 \Delta h_{\mathrm{L}}^{\theta} \quad$ standard low heating value of oil shale, $\mathrm{kJ} / \mathrm{kg}$

$24 \Delta h_{\mathrm{H}}^{\theta} \quad$ standard high heating value of shale oil, $\mathrm{kJ} / \mathrm{kg}$ 


$$
\begin{aligned}
& 1 \quad k \quad \text { reaction rate constants, } \mathrm{s}^{-1} \\
& 2 \mathrm{R} \text { gas constant, } 8.314 \mathrm{~kJ} / \mathrm{kmol} \cdot \mathrm{K} \\
& 3 s \quad \text { entropy, } \mathrm{kJ} \mathrm{mol}^{-1} \mathrm{~K}^{-1} \\
& 4 T \text { temperature, } \mathrm{K} \\
& 5 A \text { pre-exponential factor } \\
& 6 t \text { time, } \mathrm{s} \\
& 7 x \text { the concentration at a time } \mathrm{t}, \mathrm{kg} / \mathrm{m}^{3} \\
& 8 y \text { exergy destruction ratio, } \% \\
& 9 \text { Subscripts } \\
& 10 \mathrm{~F} \text { fuel } \\
& 11 \mathrm{P} \quad \text { product } \\
& 12 \text { D destruction } \\
& 13 \mathrm{~L} \quad \text { loss } \\
& 14 \text { C collecting tube } \\
& 15 \text { W washing tower } \\
& 16 \text { I indirect cooling tower } \\
& 17 \text { E electric oil separator } \\
& 18 \mathrm{H} \text { heating furnace } \\
& 19 \mathrm{k} \quad \mathrm{k}^{\text {th }} \text { component } \\
& 20 \text { tot total } \\
& 21 \text { ph physical } \\
& 22 \text { ch physical } \\
& 230 \quad \text { reference condition }
\end{aligned}
$$

\section{$24 \quad$ Superscripts}

25 AV avoidable

26 EN endogenous

27 EX exogenous

28 UN unavoidable

\section{Greek Letters}

$30 \quad \varepsilon \quad$ exergy efficiency, $\%$ 
$1 \omega \quad$ mass fraction of water in oil shale, $\%$

2 


\section{References}

2 [1] Han XX, Kulaots I, Jiang XM, Suuberg EM. Review of oil shale semicoke and its combustion utilization. Fuel 2014; 126: 143-61.

[2] Wang J, Feng L, Steve M, Tang X, Gail TE, Mikael H. China's unconventional oil: A review of its resources and outlook for long-term production. Energy 2015; 82: 31-42.

[3] International Energy Agency (IEA). World Energy Outlook 2014. International Energy Agency. Paris, France, 2014.

[4] Zhao C, Chen B. China's oil security from the supply chain perspective: A review. Appl Energy 2014; 136: 269-79.

[5] Han XX, Niu MT, Jiang XM. Combined fluidized bed retorting and circulating fluidized bed combustion system of oil shale: 2. Energy and economic analysis. Energy 2014; 74: 788-94.

[6] Wang Q, Zhao W, Liu H, Jia, C, Li S. Interactions and kinetic analysis of oil shale semi-coke with cornstalk during co-combustion. Appl Energy 2011; 88(6): 2080-7.

[7] Yang QC, Qian Y, Wang YJ, Zhou HR, Yang SY. Development of an Oil Shale Retorting Process Integrated with Chemical Looping for Hydrogen Production. Ind Eng Chem Res 2015; 54, 6156-64.

[8] Qin H, Yue YK, Liu HP, Wamg Q. Current status and prospect of oil shale retorting technologies in China. Chem Ind Eng Prog 2015; 34(5): 1191-8(in Chinese).

[9] QianY, Yang QC, Zhang J, Zhou HR, Yang SY. Development of an integrated oil shale retorting process with coal gasification for hydrogen production. Ind Eng Chem Res 2014; 53 (51): 19970-8.

[10] Yang SY, Zhang J, Yang QC, Qian Y. Development of an integrated oil shale retorting with retorting gas steam reforming for hydrogen production. Energy Fuels 2014; 28(8): 5557-64.

[11] Bai Z, Bai JR, Wang Q, Li XM. Process simulation for Huadian-type oil shale retorting system by Aspen Plus. CIESC J 2012, 63 (12): 4075-80 (in Chinese).

[12] Wang Q, Zhang FZ, Liu HP, Wang ZF, Sun K. Simulation of dry distillation process of oil shale in heat gas. CIECS J 2012; 63(2): 612-7 (in Chinese).

[13] Wang S, Jiang X, Han X, Tong J. Investigation of Chinese oil shale resources comprehensive utilization performance. Energy 2012; 42 (1): 224-2.

[14] Bai Z, Bai JR, Wang Q, Li XM. Process simulation and analysis of the Fushun-type oil shale

[15] Li XX, Zhou HR, Wang YJ, Yang SY. Thermoeconomic analysis of oil shale retorting processes with gas or solid heat carrier. Energy 2015; 87: 605-614. 
[16] Wang L, Yang Y, Morosuk T, Tsatsaronis G. Advanced thermodynamic analysis and evaluation of a supercritical power plant. Energies 2012; 5(6): 1850-63.

[17] Boyaghchi FA, Molaie H. Sensitivity analysis of exergy destruction in a real combined cycle power plant based on advanced exergy method. Energy Convers Manage 2015; 99: 374-86.

[18] Vatani A, Mehrpooya M, Palizdar A. Advanced exergetic analysis of five natural gas liquefaction processes. Energy Convers Manage 2014; 78: 720-37.

[19] Petrakopoulou F, Tsatsaronis G, Morosuk T, Carassai A. Conventional and advanced exergetic analyses applied to a combined cycle power plant. Energy 2012; 41(1): 146-52.

[20] Tsatsaronis G, Morosuk T. Advanced exergetic analysis of a novel system for generating electricity and vaporizing liquefied natural gas. Energy 2010; 35: 820-9.

[21] Morosuk T, Tsatsaronis G. Comparative evaluation of LNG e based cogeneration systems using advanced exergetic analysis. Energy 2010: 1-8.

[22] Wang L, Yang Y, Morosuk T, Tsatsaronis G. Conventional and advanced exergetic evaluation of a supercritical coal-fired power plant. In: 25th international conference on efficiency, cost, optimization, simulation and environmental impact of energy systems; 2012.

[23] Olaleye AK, Wang M, KelsallG. Steady state simulation and exergy analysis of supercritical coal-fired power plant with $\mathrm{CO}_{2}$ capture. Fuel 2015; 151: 57-72.

[24] Petrakopoulou F, Lee YD, Tsatsaronis G. Simulation and exergetic evaluation of $\mathrm{CO}_{2}$ capture in a solid-oxide fuel-cell combined-cycle power plant. Appl Energy 2014; 114: 417-25.

[25] Tsatsaronis G, Morosuk T. Advanced exergetic analysis of a refrigeration system for liquefaction of natural gas. Int J Energy Environ Eng 2010; 1: 1-17.

[26] Morosuk T, Tsatsaronis G. A new approach to the exergy analysis of absorption refrigeration machines. Energy 2008; 33: 890-907.

[27] Morosuk T, Tsatsaronis G, Zhang C. Conventional thermodynamic and advanced exergetic analysis of a refrigeration machine using a Voorhees' compression process. Energy Convers Manage 2012; 60: 143-51.

[28] Erbay Z, Hepbasli A. Application of conventional and advanced exergy analyses to evaluate the performance of a ground-source heat pump (GSHP) dryer used in food drying. Energy Convers Manage 2014; 78: 499-507.

[29] Yang QC, Zhang J, Yang SY, Qian Y. Modeling and techno-economic analysis of the oil shale comprehensive utilization process. CIESC J. 2014, 65, 2793-2801 (in Chinese).

[30] Morosuk T, Tsatsaronis G. Advanced exergetic evaluation of refrigeration machines using different working fluids. Energy 2009; 34(12): 2248-58.

[31] Li S, Ji X, Zhang X, Jin H. Coal to SNG: Technical progress, modeling and system optimization through exergy analysis. Appl Energy 2014; 136: 98-109. 
[32] Fang C, Li S, Ma G, Wang H, Huang Z. Reaction mechanism and kinetics of pressurized pyrolysis of Chinese oil shale in the presence of water. Petrol Sci 2012; 9(4): 532-4.

[33] Lü X, Sun Y, Lu T, Bai F, Viljanen M. An efficient and general analytical approach to modelling pyrolysis kinetics of oil shale. Fuel 2014; 135: 182-7.

[34] Szargut J, Morris DR, Steward FR. Energy analysis of thermal, chemical, and metallurgical processes. New York: Hemisphere Publishing Corporation; 1988.

[35] Yang SY, Yang QC, Qian Y. A composite efficiency metrics for evaluation of resource and energy utilization. Energy 2013; 61: 455-62.

[36] Callak M, Balkan F, Hepbasli A. Avoidable and unavoidable exergy destructions of a fluidized bed coal combustor and a heat recovery steam generator. Energy Convers Manage 2015; 98: 54-8.

[37] Pavelka M, Klika V, Vágner P, Maršík F. Generalization of exergy analysis. Appl Energy $2015 ; 137,158-72$.

[38] Bejan A, Tsatsaronis G, Moran M. Thermal design and optimization. New York: Wiley; 1996.

[39] Wang JJ, Yang K, Xu ZL, Fu C. Energy and exergy analyses of an integrated CCHP system with biomass air gasification. Appl Energy 2015; 142: 317-27.

[40] Man Y, Yang SY, Zhang J, Qian Y. Conceptual design of coke-oven gas assisted coal to olefins process for high energy efficiency and low CO2 emission. Appl Energy 2014; 133: 197-205.

[41] Yang QC, Yang SY, Qian Y, Kraslawski A. Application of House of Quality in evaluation of low rank coal pyrolysis polygeneration technologies. Energy Convers Manage 2015; 99: 231-41.

[42] Tsatsaronis G. Exergoeconomics and exergoenvironmental analysis. In: Bakshi BR, Gutowski TG, Sekulic DP, editors. Thermodynamics and the destruction of resources. New York: Cambridge University Press; 2011; 377-401.

[43] Chen J, Havtun H, Palm B. Conventional and advanced exergy analysis of an ejector refrigeration system. Appl Energy 2015; 144: 139-51.

[44] Morosuk T, Tsatsaronis G. Advanced exergy analysis for chemically reacting systems-application to a simple open gas-turbine system. Int J Thermodyn 2009; 12(3): 105-11.

[45] Kelly S, Tsatsaronis G, Morosuk T. Advanced exergetic analysis: approaches for splitting the exergy destruction into endogenous and exogenous parts. Energy 2009; 34: 384-91.

[46] Han XX, Jiang XM, Cui ZG. Studies of the effect of retorting factors on the yield of shale oil for a new comprehensive utilization technology of oil shale. Appl Energy 2009; 86 (11): 2381-5.

[47] Niu M, Wang S, Han X, Jiang X. Yield and characteristics of shale oil from the retorting of oil shale and fine oil-shale ash mixtures. Appl Energy 2013; 111: 234-9. 